\title{
綠膿菌耳翼軟骨膜炎二關スル實驗的研究
}

\section{第五編 抗綠膘菌免疫血清キ注射七シ場合}

\author{
A. Arai : Study of Inflammation of Perichondrium of the Pinna. \\ Caused by Bacilli of Green Puss. (Bacillus Pyocianeus.) \\ Part. V: Experiments on Rabbits treated \\ with Anti-bacteria Serum.
}

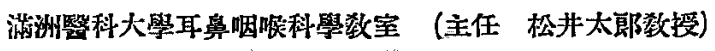

醫學士 荒蓝”章

目次

\author{
第一章 緒 論 \\ 第二章 實驗 記 载 \\ 第一節 使用動物

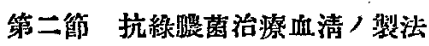 \\ 第三節 實驗方法 \\ 第四節 惯驗動物 訅載
}

\section{第 一 章}

緒

論

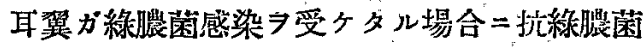
治療血清ガ治療上效果有ル十否ヤ二就テ，研筧 八未ダ何人ニヨツテモ行ハレタルコトナシ。

余八罴/實驗（売井：線膘菌耳翼軟骨膜炎二關 スル實驗的研究。第 2 編)=於テ得タル處ノ抗綠 膿菌血清 於テ實驗的二研究シタリ。

\section{第 二 章}

\section{蕢 羷 記 載}

\section{第一節 使 用 動 物}

鳢重 $2 . \mathrm{kg}$ 内外ノ健康ナル 全身及ビ耳焉泣

$$
\begin{aligned}
& \text { 第五節 對照㖶物 記載 } \\
& \text { 第三龺 總括及ビ考桑 } \\
& \text { 第四章 結論 }
\end{aligned}
$$

=中耳二何等ノ變化 7 認メザル家鬼 リ。

第二篩 抗椂膿菌治療血清，㹈法

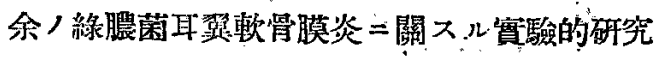
第 2 編第 1 實驗二於ケル。第 42 號. 第 46 號。 第 47 號. 第 60 號. 第 74 號. 第 90 號. 第 91 號 動物耳㾞 7 沃度丁幾 7 以ラ嚴密 $=$ 消毒シタル後 二耳静胍ノ一ヨ遙ビ. 該靜脈 7 耳翼基部 $=$ 於テ 原迫シ。該靜脈ガ十分二怒張スルタ待ッテ、太 キ注射針 7 以テ該靜胍ノ一部二損㑑 次デ此損偤部ョり流出スル血液 減菌試驗管二 受ケテ探血ス。試驗管內，血液八試驗管 7 科位 =約 1 時間室温=放䁂スレバ凝血ス。次デ燒灼 減菌セル白金線 叟離シ。冷室 $=24$ 時間試驗管 7 直立セシメテ 
放置スレバ血清ノミ八榙色淕明ナル液トシテ凝 血ヨリ分噰ス。該血渄习減菌セル注射器 探取シテ別，減菌試驗管内二移ス。之 $556^{\circ} \mathrm{C}=$ 30 分閒加熱シ非活動性ノ血清トナス。次デ 0,5 \% 割 =石炭酸 7 注加ス。之ヨ本實驗ノ綠膿菌 治療血湍トシテ使用ス。而シテ之等血清八綠晨 菌 PA 秼=對シテ 6400 倍以上ニテ陽性/凝集 反應习呈スルモノナリ。

\section{第三節 䆩 驗 方 法}

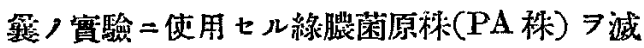
菌生理的食監水 $1.0 \mathrm{cc}=1$ 白金耳 $(1 . \mathrm{mg}) /$ 割 $=$ 浮游七シメタル菌漂游湤

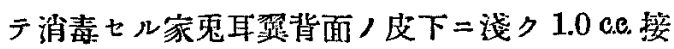

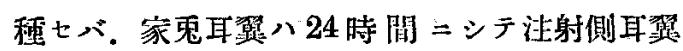
全面二發赤 ス。此際郎于發病 24 時間 目二前記治療血源 7

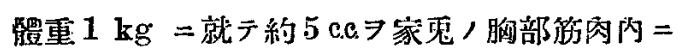
注射シテ其後,耳翼ノ變化 7 觀察シタリ。

而シテ注射遖後ハ注射部位ナル胸部 $=$ 膨隆ヨ來 タスモ短時間 $=シ テ$ 全ク吸收サレ注射部位 $=$ 變 化习認メタルモノナシ。

又治療血清 7 注射シタル第 $メ$ 異常ナル全身症 状又八發作ヨ迪シタルモノモ热シ。

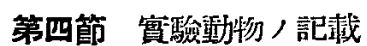

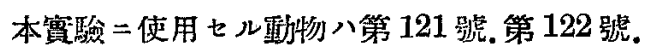
第 1.23 號. 第 124 號. 第 125 躆/5頭ナリ。备 哑物フ記載スレバ次ノ如シ。

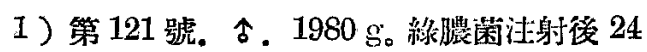
洔間ニシテ先注射側耳翼，毛細血管八耳翼ノ全 面二著シク怒張シ。注射部位二於テハ堙脹シ。

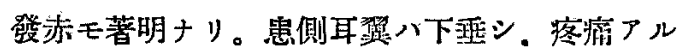

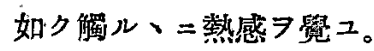

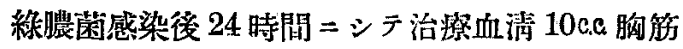

肉二注射不。

治㩐血清注射後份木耳翼/發赤腫脹八進行性＝ 㙁昰シ．且ツ疼痛モアル如ク一般狀態亦不良=

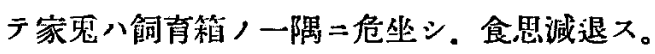
而シテ絈蜄菌感染後 5 日二於テハ耳翼/症狀八 娍退シ來タリ，發赤腫脹減ジ。一般狀態亦正常 =復ス。其後沿次耳翼, 發赤属脤去り感染媵 10 日二至レバ注射部位二粱粒大ノ結節 7 止メ.

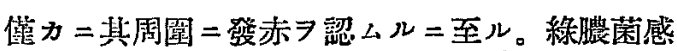
染啳15日 =至レバ㱠ンド肉眠的二八何等／裉跡

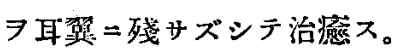

「エピクリーゼ」。耳翼二綠膿菌感染後 24 時間

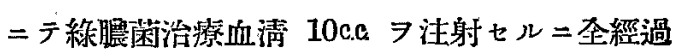
15日 シシテ何等，變形 7 耳翼ニ殘スコトナク全 治ス。(附喟第 1 四)。

2）第 122 號. 今 $1950 \mathrm{~g}$ 。桷膿菌 PA 注射 後 24 時間二於分几注射側耳翼，所見八第 121

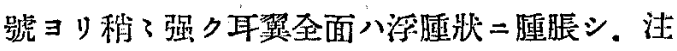
射部位八曋紫色 7 呈ス。

緮膿菌感染後 24 時間ニシテ治潦血清 10c.e. 胸筋 肉二注射入。

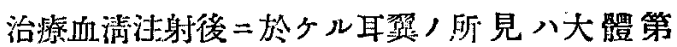
121 號ト大差ナシ。綠蚫菌感染後 5 日ニシテ發 赤腫脹最モ强キ部位, 中央稍了內陷シ。該部位 八溃湯トナリ血性膿性分泌物 フ件ヒ其表面ニハ

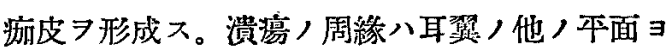
リ堤防㸛二隆起ス。潰場部八夫レョリ次第 $=$ 清

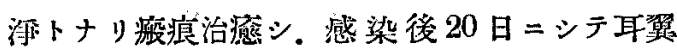
，中央部二小指頭大／偟痕形成シテ治ス。而シ テ治療血清ノ注射 テテハザル場合二見ル如キ耳 翼尖端部/塤死. 又八耳翼, 著シキ畸形 7 起ザ ズ。

「エピクリーゼ」。耳翼二綠㤟菌感染後 24 時間 


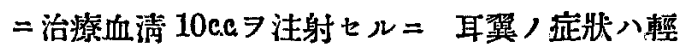
症二經過シ．全經 過 20 日ニシデ綠膘菌注射部 位二小指頭大，般痕习殘シテ全治ス。耳翼尖端 部ノ壤死モ起サズス後 =耳翼ノ畸形 $モ$ モ殘サ x。

3) 第 123 號。合. $1890 \mathrm{~g}$ 。緣膿菌 PA 注射 後 24 時間二於ヶル耳翼/變化八第 122 號ノ如 ?感染耳翼八强ク浮腫狀二腫脹シ。特二洼射部 位二發赤尰脹强シ。耳翼八患側下垂シ。疼痛 培フルガ如シ。

綠膿菌感染後 24 時間ニシテ治療血清 $100 \mathrm{cc}$ ，胸 部筀肉内二洼射ス。

治㞠血清注射後兩三日，經過八第 121 號二見夕 ル如り症状八靚進的ナリ。感染後 5 日ニシテ耳

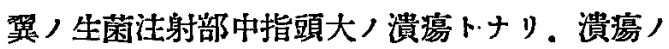

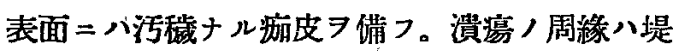
防狀二隆起スルニ至リシガ其後八漱㳄潰湯ノ炎 症八消散シ，清浮トナリ，縮小シ。洀痕生ジ。

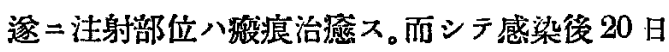
シシデ洀痕部八僅カニ收縮シテ. 周圍多少凹凸 ス。サレド耳翼ノ壊死，耳翼全面ノ著シキ猗形

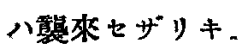

「エピクリーゼす。耳翼二䅂膿菌感染後 24 時間 目二治潦血清 10c.c. 习注射万。患側耳翼注射部 二全經過 20 日ニシテ周緑不整ノ小ナル洀痕 形成スルノぞテ全治ス。而シテ耳翼尖端ノ壤

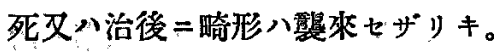

4）第 124 號。令. $1975 \mathrm{~g}$ 。㴝膿菌 $P A$ 注射 後 24 時間二於ケル耳翼，所見八第 121 號二見 タル處ト大差ナシ。

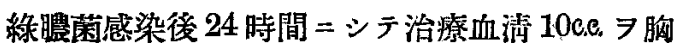
部觔肉内 =注射又。

治源血清注射後，經過八第 122 號㭧側耳翼所見
ト同栐ニシテ感染後 14 日ニシテ綠膿菌注射部 位ニ小ナル湤痕ヨ形成シテ治瘾ス。

「エピクリーゼ」。耳翼二綠䐵菌感染後 24 時間

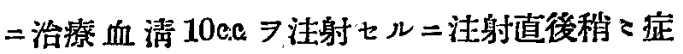
㥭增進セルモ早ク退化セシメ感染後 14 日ニテ 注射部位二僅カー小ナル般源ヨ止メラ全治”。 耳翼全般ノ腫脹。耳翼尖端部ノ壞死シ起サズ= 終り治後畸形习殘サ・リキ。

5) 第 125 號：令. $1898 g$ 。綠膿菌 PA 注射 後 24 時間 =於ケル耳翼, 變化ハ第 121 號, 所 見ト大差ナシ。

綠膿菌感染 後 24 時間ニシテ治潦血清 $9 \mathrm{ccc}$ 胸 部皦肉內二注射入。

治療血清注射啳ノ經過モ大體 121 號，經過卜同 栏ニテ感染後 25 日ニシテ何等, 狼跡》患側耳 翼二殘スコトナり全治ス。

「エピクリーゼ」。耳翼二緣膿菌感染後 24 時間 二治療血清 $9 \mathrm{cc} .7$ 注射七ル二全經過八感染後 25 日 =テ耳翼=何等ノ痕跡フ殘サズ全治シ．耳 翼儿壞死：耳翼; 廣沉ナル畸形习殘サ・リキ。

第五節 對照動物ノ記載

第 126 號．㐱。1960 g。綠膿菌PA 注射後 24 時間二於ケル耳翼，變化八第 121 號二見タル處 ト大差ナシ。

綠膿菌感染 後 24 時 間二綠膿菌＝低りテ何等， 免疫操作 菌 = 對スル乔度抗體 有セザル血清 トナシタルモ１0ec，７胸部筋肉內＝注射ス。 血清注射後モ耳翼/症狀八增進的ニシテ血清注 射後 4 日二至ルモ耳翼，發赤腫脹八传然全耳翼 二亘りテ强ク，緣膿菌注射部位二分拇指頭大， 溃暗形成シ。溃演，周圍八堤防狀=隆起又。耳 翼尖端部 $=$ 於テ八感染後 5 日頃 $コ$ 血清分泌物 


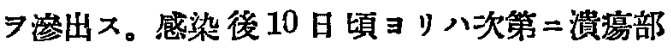
ノ表面八乾燥シ. 踇痕化シ. 感染後 15 日二至レ

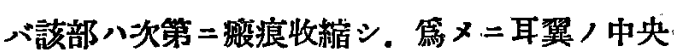
部ハ變形 7 星シ又耳翼尖端部モ洀痕性 =治答シ

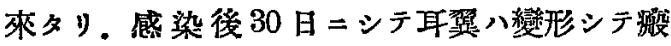
痕全治ス。

「エピクリーゼ」。耳翼二綠膿菌感染後 24 時間 =何等 嬠作 7 加へザル健康家鬼，血清 710 c.c注射七シ＝，患側耳翼八感染後25日ニシテ耳 翼ハ注射部位及ビ尖端部二激痕收縮タ來タシ。 耳翼畸形

\section{第三草 \\ 總 括 及ビ考案}

余八實驗動物總數 5 頚 =於テ耳翼二綠膿菌感 染後 24 時間 $=シ テ 6400$ 倍强陽性ノ凝集價 $\ni$ 有 スル該綠膿菌二依儿倇复血清 7 體重 $1 \mathrm{~kg}=$ 就テ

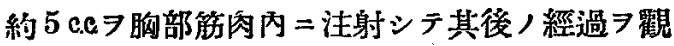
察七シニ．5頭中 2 頭八緮膿菌感染部位ノ發赤

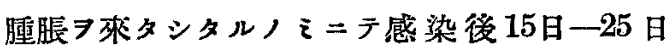
ニテ全治シ.何等肉眼的二變化 頭八感染部位 $=$ 感染後 5 日一 7 日ニシテ小指頭 大乃至中指頭大/溃湯 7 形成シタふモ感染後14

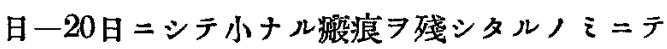

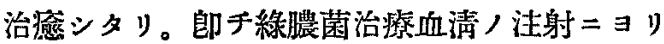
テ其紽澧菌感染耳翼ノ症狀ノ進行

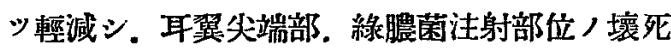
フ起サズ。其治癒後二モ耳翼，畸形フ殘サ・ル ア認メ得タリ。

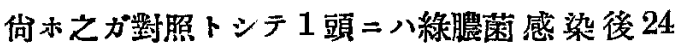
時間ニシテ綠膿菌冤疫抗體シ有セザル正常家鬼 ，血清 7 顝重 $1 \mathrm{~kg}=$ 就テ約 $5 \mathrm{ccc}$ 注射シテ粯察シ タルニ. 對照動物二沾テハ感染挠 25 日ニシテ
注射部位及ビ耳翼尖端二隺痕收縮 フ來タシテ耳 翼畸形ラ殘七り。即千單ナル血清注射二テハ維

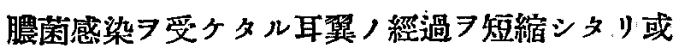
八其症狀习遮止スルコトラ認メラレザリキ。耳 翼ガ綠膿菌感染 7 受ケタル場合二其冤疫血清ガ 洽療ノ效果 八米ダ試ミラレタルコトナシ。

ワ,セルマン八淥膿菌ノ治療血清习製シテえア 一般外科，創面二感染七シ綠膿菌，撲減二使用 シタリト云フモ其效果二就テノ記載ハナシ。ナ ターール・ギルダースレーブハ抗綠膿菌血清中 ニハ「オプソニン」. 抗毒素. 凝集素ヨ有シ. 治療二用フレバ效果ヨ有セント記載ス。とトテ モ果シテ效果アリシヤ否ヤ二關シテハ記载 ズ。

從來耳翼ガ綠膿菌感染受ケタル時二著シク洧 垩性ナル耳翼堹骨膜炎习起シ。多ク/場合其治 恣スルヤ耳翼畸形フ殘スコト八到底忽レザル事

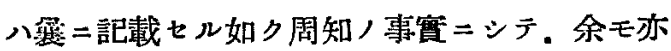
之ア䆵驗的二確メ得タル處ナリ(荒井: 緣膿菌耳 翼軟骨膜炎二關スル實匳的研究. 第 1 編參照)。 サレド其治潦法＝關シテハ現今二於テモ唯單 = 對症療法 有セズ。故二余八本編, 實驗例ノ示スガ如ク耳

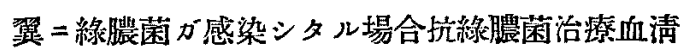

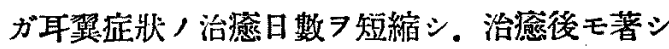
キ耳翼, 畸形 殘サ、゙ルモノトスレバ將來人體 二於ケル場合二モ試にラルぺキ一方法ナラント 主唱スルモノナリ。

\section{第 五 章}

結

論

1 ) 綠膿菌炛疫血清八家兔二於テ形成七ラ 
ル。

2）該免疫血清八家鬼二於テ繖澧菌軟骨膜炎 ノ证狀 畸形等ノ殘查症 7 起サズ。泡治療的效價 7 有
ス。

3）單純ナル健康家槵血清注射二テハ耳翼堹 写膜炎, 症彇經過二變リナシ。

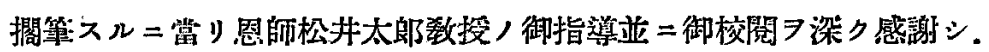

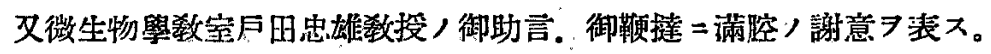

\section{主 要 文 献}

1) Denker u. Kahler: Handbuch. d. H. IV. O-heilkunde. 192\%. 2) Katz: Handbuch d. speziellen Chirurgie. d. Ohres. usw. Bd. 2, 1922.

3) Kolle n. Wassermann: Handbuch d. pathogenen Mikroorganismen. BC.. 6, 1924. . 4) Natha- niel Gildersleeves: Jour. A. M. Vol. LVIII. No. 4, P. 287, 1911. 5) Wassermamm, A.: Zschr. f. Hyg. Vol. XIII. S. 267, 1903. 6)

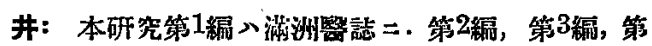
4編. 大日耳學. 1936 .

\section{附 圆 說 明}

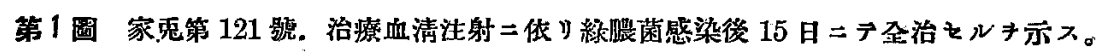




\section{荒 井 論 文 附 圖}

\section{緣㵵菌耳翼㳄骨膜炎＝關 スル寒驗的研究（第五編）}

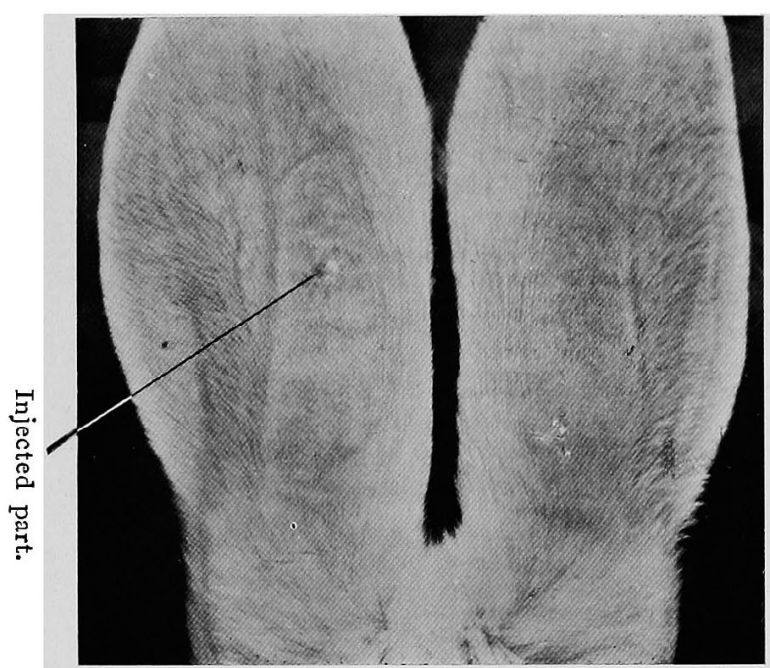

No. 125 animal. 15 days sight after injected with pyocyaneus-immune-sera.

A. Arai: Study on Inflammation of Perichondrium of the Pinna. Caused by Bacilli of Green Pus. (Bacillus Pyocianeus.) Part. V: Experiments on Rabbits treated with Anti-bacteria Serum. 